\title{
Sustainability Challenge for Academic Libraries: Planning for the Future
}

\author{
Maria Anna Jankowska and James W. Marcum
}

There is growing concern that a variety of factors threaten the sustainability of academic libraries: developing and preserving print and digital collections, supplying and supporting rapidly changing technological and networking infrastructure, providing free services, maintaining growing costs of library buildings, and lowering libraries' ecological footprint. This paper discusses the multidimensional issues of sustainability in academic libraries and identifies needs for designing an integrated framework for sustainable strategies in academic libraries. Additionally, the paper presents a synthesis of existing literature on the increasingly popular topic of "green libraries" and prepares a background toward developing a framework for sustainable strategies in academic libraries.

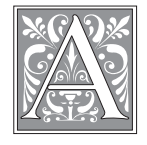

paradox of modern academic libraries is that, while they strive to introduce new technologies to respond to evolving user information needs, they are still mostly organized around traditional information formats. A large part of the library building's spaces are dedicated to shelving for books, print, and digital materials. A major public perception survey demonstrates that books continue to be the library's brand. ${ }^{1}$ In the digital age, this poses a challenge for the economic sustainability of libraries, since brands are difficult and costly to change. The value and utility of the book is coming under increased scrutiny, largely due to the fact that users are trading off physical access to print books and research journals for the convenience and speed of virtual access to digital materials. Considering the trend toward digital collections and social networking services, the key concern is whether the blended model of traditional (mostly based on print resources) plus hybrid (based on mixes of print and digital resources) and a new Library 2.0 (based on social networking services) model is socially, economically, and environmentally sustainable.

Digital formats and networking services are costly and require extensive technical, human, and financial support. Additionally, they consume considerable quantities of energy and water, as well as ink and paper for printouts. Developing a blended model of print and digital resources supported by social networking services has raised a major concern that sustainable progress of academic libraries is threatened by a variety of factors such as: developing and preserving print and

Maria Anna Jankowska is Social Sciences Librarian in the Charles E. Young Research Library at UCLA; e-mail: majankowska@library.ucla.edu. James W. Marcum is University Librarian at Fairleigh Dickinson University; e-mail: marcumjw9@aol.com. (cMaria Anna Jankowska and James W. Marcum 
digital collections, supplying and supporting rapidly changing technological and networking infrastructure, providing free services to the public, maintaining growing costs of library buildings and lowering libraries' "ecological footprint." This paper addresses these challenges and identifies needs for designing an integrated framework for sustainable strategies that would help academic libraries to become more sustainable organizations. It is not the objective of this paper to develop such a framework. However, this paper presents the extended review of literature on this increasingly popular topic and prepares groundwork for future research on an integrated framework for sustainable strategies in academic libraries.

\section{Library Sustainability: A Literature Review}

In 1987 the United Nations' World Commission on Environment and Development (WCED) came out with a report entitled "Our Common Future," which presented the idea of sustainable development calling for socially and environmentally sound approaches to economic growth. The report defined sustainable development as a balance between social equity, economic growth, and ecological concerns "that meets the needs of the present without compromising the ability of future generations to meet their own needs." ${ }^{2}$ Since then, the issue of sustainable development has moved beyond the U.N. and environmentalist declarations. In 1990, twenty-two university presidents from all over the world signed the Talloires Declaration in France creating the Association of University Leaders for a Sustainable Future (ULSF). With their signature they committed their higher education institutions to incorporate sustainability and environmental literacy into research, teaching, outreach, and university and college operations. ${ }^{3}$

After 1990, the concept of sustainability penetrated economic and social growth agendas and influenced academic communities in more than 350 institu- tions of higher education. A sustainable community, as defined by Sustainable Communities Network (CONCERN, Inc.), is one that "uses its resources to meet current needs while ensuring that adequate resources are available for future generations. It involves all its citizens in an integrated, long-term planning process to protect the environment, expand economic opportunities and meet social needs. ${ }^{4}$ In this context, sustainable growth is essential for institutions and organizations to thrive and contribute meaningfully to the communities around them. As part of the university community, academic libraries need to participate more forcefully in this effort.

Since the 1990s, library literature on sustainability and environmental concerns has grown and garnered much attention. This review identifies four major categories:

(1) Sustainability of scholarship and collections;

(2) Green library operations and practices;

(3) Green library buildings; and

(4) Measuring and improving sustainability.

\section{Sustainability of scholarship and collections}

Authors writing on this topic focus on sustainability of scholarly communication and information in digital and print collections. They understand sustainability as an effort to maintain and secure research collection for future generations or, in the case of scholarly communication, as an endeavor to make them independent from commercial publishers. In scholarly communication, the term "sustainable publication" refers to new methods of publications in such formats as: pre- and post-publication prints, open-access and author-pay models, subscription-based electronic journals, institutional repositories, personal blogs, and multimedia publications. Kings and others state "any sustainable means of publication must combine that perception with (1) recognition and apprecia- 
tion within the academic reward system and disciplinary value system and (2) business models that are sustainable for all concerned in the publication chain." ${ }^{5}$ Taken together, university libraries and presses, ${ }^{6}$ organizations, and archives offer alternate paths to enabling and preserving scholarly communication and making it available to the public, but this model requires more cooperation for effective implementation. ${ }^{7}$

Digitization and preservation offer enormous potential to secure not only library collections and materials for future generations but also reduce costs associated with managing print collection. For example, the JSTOR project not only intended "preservation of scholarship" but also reduced costs associated with the managing of print journals. ${ }^{8}$ However, research on digitization and preservation is still in its early stages ${ }^{9}$ and libraries need to resolve important complexities in building sustainable digital collections. Leading issues include: using proper technologies, ${ }^{10}$ selecting compatible standards, ${ }^{11}$ avoiding commercialization, ${ }^{12}$ securing economic sustainability for created projects, ${ }^{13}$ and achieving continuity and the sustainability of digital collections. ${ }^{14}$

Altogether, authors in this group focus mainly on the sustainability of scholarly communication and information, the challenges of maintaining print and digital collections indefinitely, and finding answers to the question posed by Deanna Marcum: "How do scholars and librarians work together to ensure that resources created today will be available in the future?"15 Clearly, sustainability of scholarship is inherently linked with sustainability of collections and services.

\section{Green library operations and practices}

Several authors in this group concentrate on "green" concerns and practices already in place in academic libraries. As Le Bern and Gregory state, "greening is a process, as well as a state of mind, and it calls for taking action. Greening involves a spirit of reciprocity. We take care of the environment that takes care of us, cultivating a relationship with the natural world that sustains us."16 The American Library Association's (ALA) Task Force on the Environment (TFOE) pioneered "green" concepts in librarianship. Since 1990, TFOE has aimed at making libraries and the public aware of diverse environmental information sources, addressed and sought out solutions to green concerns and practices in libraries, worked on greening ALA conferences, and promoted awareness of environmental issues in the ALA and library community. The Task Force has been educating librarians and the public by organizing environmentally focused programs and providing an open-access platform for scholarly environmental communication with the Electronic Green Journal. ${ }^{17}$ Most recently, the Task Force initiated the "Librarians Raise Their Cups for Planet Earth" project asking librarians to bring their own coffee mug to the 2008 ALA conference in Philadelphia. ${ }^{18}$ Additionally, the 14th ACRL Conference in Seattle considered "green" as a major theme of the last conference and focused on green points. ${ }^{19}$

Since the 1990s the popularity of green topics has expanded steadily from "green librarian," 20 "green librarianship," 21 "green academic sector," 22 "greening college libraries," 23 "greening libraries," 24 "green blogs," 25 to "go green," 26 and "green library movement." 27 Also, the literature reporting on green library practices addresses recycling, ${ }^{28}$ noise, ${ }^{29}$ and paper use. ${ }^{30}$ Additionally, the literature presents discussion of environmental user education and environmental literacy represented by contributions from Link, Jankowska, ${ }^{32}$ Stoss, ${ }^{33}$ Weintraub, ${ }^{34}$ Shrode, ${ }^{35}$ and Rome. ${ }^{36}$

Primary concerns of this literature include actions that help the greening of academic libraries, but, as Katherine Dike concludes, "many library services were carrying out green practices, in particular recycling, in the absence of institutionwide green policies." ${ }^{37}$ 


\section{Green library buildings}

Authors addressing the green library building theme discuss architectural designs that consider sustainable solutions in renovating or building libraries. Library buildings use significant quantities of electricity, energy, and water, as well as forest for paper. They also produce significant amounts of solid waste. Since 2000, the Leadership for Energy and Environmental Design (LEED) has disseminated codes and standards for green certification for renovation and new constructions developed by the U.S. Green Building Council. The need for creating green and sustainable library buildings was promoted early on by Weiner and Boyden $^{38}$ and Brown. ${ }^{39}$

In the early 1990s many public libraries adopted green concepts in their buildings. ${ }^{40}$ Green buildings are energy efficient; use nontoxic recycled-content materials and furniture, natural daylight, and low-flow toilets; and reduce maintenance costs. The Libris Design Project provides detailed design planning and documentation starting from acoustics for libraries through interior finish materials for library technology infrastructure design. ${ }^{41}$ Also prominent is the literature on designing library spaces to facilitate the library's new role as a research and learning center as opposed to a traditional depository center. ${ }^{42}$ This literature presents sustainable designs for library building interiors and exteriors and promotes responsible use of renewable and nonrenewable resources to achieve healthy and pleasant conditions for the library users while providing good conditions for the collections and services. Answering the question "why should libraries be sustainable buildings?" Johanna Sands explains:

"Libraries serve as symbols of the attitudes and values of their creators and can serve to extend those attitudes and values to future generations of occupants and visitors. Communities with the opportunity to build a new library or update an existing library should prioritize sustainable design measures." 43

\section{Measuring and improving sustainability}

Another emerging literature focuses on measuring progress toward sustainability following the United Nations recommendations published in 1966, "Indicators of Sustainable Development: Framework and Methodologies." ${ }^{44}$ Since the publication of those recommendations, the literature and projects on national, ${ }^{45}$ regional, community, and institutional indicators measuring social, economic, and environmental progress has grown considerably. Growing commitment of universities and colleges to environmental sustainability has resulted in the vast literature devoted to issues of sustainability for university campuses. ${ }^{46}$ Assessment reports and projects conducted by many universities and colleges (among them are Western Michigan University, Penn State, Furman, Concordia, or Michigan State) play an important role in this regard. ${ }^{47}$

However, the literature on sustainable university and college campuses does not treat libraries as distinct entities. By and large, there is a lack of sufficient data on sustainable and environmental performances of academic libraries. Von Deventer and Snyman ${ }^{48}$ propose a multidimensional measurement framework for libraries and information services that focuses on economic sustainability - similar to a recent Ithaka Report. ${ }^{49}$ Academic libraries could easily adopt already well established sustainability assessment tools used in higher education..$^{50}$ Research on the feasibility of transplanting the most suitable assessment tools from campuses into academic libraries still needs to be carried out. In 2008, Primary Research Group published a national survey of academic, public, and special libraries on energy use and conservation practices. Results of the survey could allow crossorganizational comparison and assessment of library energy use and conservation. ${ }^{51}$ In the future, data from this survey could be instrumental for research on establish- 
ing needed policies and programs for academic libraries in regard to energy use and conservation practices.

Overall, this category of literature focuses on environmental performance indicators that measure the use of nonrenewable and renewable resources for achieving sustainable growth. There is considerable room for libraries to contribute to this literature and practice.

The four presented topics characterizing the literature on library sustainability treat their respective foci separately. Consequently, different practices (greening libraries, designing green buildings, supporting sustainable collections and measuring progress) are inadequate separately to guide libraries toward sustainable progress. In this article, sustainability progress for academic libraries is synonymous with fiscally responsible, environmentally and socially acceptable growth that limits waste and thus enables equal and long-term access to library services and information resources for current and future users. Therefore, there is a need for an integrated and comprehensive framework addressing sustainability of print and digital resources and socially and environmentally responsible networking services and practices in a green library building measured by newly developed (or adapted from university and college campuses) indicators of sustainable progress.

\section{Challenges to Sustainable Future of Libraries}

Having traditionally served as central locations wherein the collection, dispersion, and constant recycling of information in both physical and digital formats occur, libraries have created an economic system of cyclical longevity and sustainability by frequently borrowing instead of constantly buying information materials. ${ }^{52}$ Yet, just as the era of digital and technological revolutions has made a significant impact on the mission and methods of libraries, this new era is seriously challenging the sustainable growth of libraries. Books and journal articles are no longer simply checked out, read, and returned. Now, multiple users can download, print, and keep the same information on multiple occasions. It is no longer enough for libraries to have print collection; instead, the expansion, creation, and preservation of collections and services have taken on new meanings. The resources and commodities (water, electricity, gas, land, and paper) consumed in these processes place a large burden on library budgets. This burden is in turn being passed on to users as small fees begin to add up, threatening the core library concept of free access to information..$^{53}$

Some basic library principles align well with major attributes of sustainability. The ALA's Task Force on the Environment states that: "the three E's - economy, ecology, and equity - provide a framework for libraries and their communities to explore and anticipate how the choices they make today affect tomorrow." ${ }^{54}$ These three E's are crucial to a library's operations and its ability to meet the information needs of current and future library users. There is, however, a fundamental contradiction between the three E's framework and the present blending model of academic libraries. Embedded assumptions of the continued growth of collections, services, and increasing costs of buildings run headlong into the requirement of sustainability. The critical challenge that academic libraries face today is the balance between the attributes of core sustainability in today's digital environment with the tradition of continued growth and the substantial environmental consumptions that growth requires.

\section{Libraries as Environmental Consumers}

Libraries consume enormous quantities of energy for user services and comfort, content creation and preservation. They produce considerable waste, particularly in energy, water, computer paper, and used electronic equipment. ${ }^{55}$ According to the report Environmental Trends and 
Climate Impacts: Findings from the U.S. Book Industry, more than 30 million trees are cut down annually for production of books sold in the United States. ${ }^{56}$ In this so-called "paperless society," the average American uses over 660 pounds of paper annually. ${ }^{57}$ Michael Kanellos writes, "Xerox says that 44.5 percent of documents are printed for one-time use and 25 percent of all documents printed get recycled the same day. Lyra Research estimates that 15.2 trillion pages get printed worldwide a year, a figure that will grow 30 percent over the next 10 years." ${ }^{58}$ Also, Donella Meadows stresses the fact that " $[\mathrm{t}]$ he average American pays $\$ 20$ a year in taxes to support public libraries and can save that much by borrowing instead of buying just one or two books. A book that is loaned 10 times cuts not only cost but paper use per read by a factor of $10 .{ }^{\prime 59}$ While many libraries deliberately and conscientiously recycle, this alone does not alleviate the problem. Continued library growth enlarges their "ecological footprint." Unless both operational costs and environmental waste are reduced in the long term, the continuous expansion of collections and services could reduce access to information to a limited number of people.

Additionally, electronic and hazardous waste is growing drastically, causing a major disparity between the goals of library sustainability and the reality of their daily operations and services. Every library shipping room constantly receives new books, periodicals, interlibrary loan orders, publisher catalogs, approval plan slip orders, correspondence, and a variety of other mail. Furthermore, each library throws away weeded and unneeded print books, government documents, magazines, newspapers, bound periodicals, microfiche, junk mail, office computer paper, and general waste. As the number of digital projects and networking functions escalates, libraries are faced with increasing energy costs, as well as the need to recycle unwanted equipment, obsolete computers, CDs, disk drives, and used computer paper.
Indicators measuring libraries as environmental consumers regarding used computer paper, water, electricity, or ink must be developed or adopted from already existing university practices. Libraries have not crafted such indicators to truck their progress toward reducing the social, economic, and environmental impacts of solid and hazardous waste and energy use. Creating or adopting already developed university campus indicators ${ }^{60}$ could assess economic, environmental, and social performance of libraries, producing budget savings and the environmental impact. These indicators should provide data on:

- The amount of water used annually by an average academic library

- The amount of solid and hazardous waste generated annually by an average academic library

- Cost reduction effected by reducing energy, water, and paper use

- Percentage of daily library shipments received that end up in garbage bins

- Percentage of publisher catalogs produced on recycled paper

- Quantity of computer paper used per library employee and user

- The amount of energy used per staff member and user

- Use of environmentally friendly inks, cleaners, and recycled paper

- Paper and equipment recycling rates

- Level of printing fees and other taxes imposed upon the users (Are these methods in line with the library's mission of free and open access to information?)

- "Ecological footprint" of the average academic library ${ }^{61}$

Reporting metrics on academic libraries' social, economic, and environmental performances would help them to understand their environmental impact and encourage the development and improvement of socially, economically, and environmentally responsible operations and services. 


\section{Need for Sustainable Growth}

Terry Link believes that only through sustainability and environmental education can higher education be transformed and saved from commercialization, and that by participating in the creation of a sustainable future, libraries can again be "the heart of the learning communities." 62 Evolving information and communication technologies, growing information needs of users, and growing operational costs of libraries create imbalances and have pushed libraries toward a more commercialized model that is goal-oriented but lacks long-term sustainable development planning. While libraries continue to thrive by meeting the information needs of their users, behind the scenes the story is different: hidden costs of library operations, buildings, collections, equipment, and supplies are growing and beginning to impact broader library goals. The traditional model of public academic libraries - to keep information open and free to all - is becoming more complicated.

Academic libraries can no longer ignore the impact of environmental consumption on their future growth. Sharing resources rather than unnecessary duplication and consumption has shaped the library economic model. However, this model does not account for growing environmental consumption and waste. The ACRL's 2007 proposed Environmental Scan, which focused mainly on sustainable library collections and services, is insufficient for sustainable growth. ${ }^{63}$ Additionally, the role of libraries in supporting global sustainability by promoting and disseminating literature on this topic and providing environmental information literacy needs to be institutionalized so that libraries can themselves become sustainable organizations adopting a model of economic progress that recognizes users' equity and shrinks libraries' "ecological footprint."

\section{Sustainable Strategies for Academic Libraries}

Changing the library into an organization more attuned to present and future users is at the heart of achieving sustainable library growth. For students, information literacy is critical; for faculty, it is support for their personal research and teaching. Unfortunately, the focus on sustaining and preserving collections at all costs is compromising libraries' chances for social, economic, and ecologically smart growth. Balancing library innovation and adaptation to this new circumstance is an important requirement for organizational sustainability. Today, organizational innovation is driven by information and communication technologies, focusing less on hierarchical control of organizations and more on building sophisticated networks of collaboration and knowledge sharing. Accordingly, libraries should think less in terms of places and more in terms of spaces. ${ }^{64}$ Those spaces must invite and encourage casual and planned gatherings to play, explore, test, share, collaborate, and learn, both formally and informally. ${ }^{65}$ Spaces can be virtual as well as real: virtual spaces are more open to networking than physical places. Boundaries fade in importance as nodes and connections emerge and become dominant in the new, open-system networked universe. Current thematic focus on preservation, print and digital collections, and networking services signal that, in today's reality, libraries cannot be responsible only for sustaining the collection and services but also must consider the relationship between space design and economic, social, and environmental sustainability.

A final requirement of sustainable organizations is the assessment of and strong interactive relations with patrons and stakeholders. Libraries are complex organizations, and they flourish by providing services others require. Any assessment of meeting sustainability objectives requires hard data, not educated guesses. This in turn requires that metrics need to be developed or adopted and implemented into daily operations. Libraries gather extensive data about services provided and can learn to better utilize that data to monitor progress toward 
meeting their sustainability objectives. Crafting new or adopting already existing metrics for tracking library performance in sustaining collections and services is at the top of our "to do" list for the future. A plan for creating a range of sustainability indicators is needed on this list. Such indicators would allow libraries to evaluate their current operational models in terms of economic feasibility, social equity, and environmental impact to support scholarship and learning. All these measures must go well beyond the perceptions and satisfaction levels of patrons or learning outcomes assessments that dominate current evaluation practices. It is a moral imperative for libraries to become sustainable organizations not only in the sense of sustaining their collections and services but also in becoming more aware of the need to "green" their buildings and operations, reduce their "ecological footprint," and ensure a better strategic position for meeting future challenges.

\section{Conclusion}

Academic libraries have always been central components of universities. With universities and colleges developing and adopting sustainability indicators, academic libraries remain slow to either develop their own sustainability indicators or to adopt indicators already developed by other organizations. Such indicators could become the basis for developing a comprehensive sustainability framework helping to assess the impacts of library operations and future projects on the library's sustainable progress. More specifically, such a framework could help libraries choose socially responsible vendors and publishers and help to evaluate operational strategies, resulting in providing environmentally friendly products, energy savings, reduction of waste, and keeping usage fees as low as possible. All libraries' strategic plans need to be grounded in the overarching framework combining the three standard dimensions (social, economic, and environmental) of sustainable growth. Sustainable strategies need to be integrated into a platform for guiding future decisions about collections, library buildings, and the scale of preservation, digitalization, equipment, products, and library networking service efforts. Such decisions need to take into account not only the cost of collection, equipment, and labor but also the cost of generated waste measured by the size of the "ecological footprint" resulting from library operations and services. Library sustainability must become a strategic consideration balancing the assumptions of continued growth and expansion.

\section{Notes}

1. OCLC. Membership Report, "OCLC. Perceptions of Libraries and Information Resources." Available online at www.oclc.org/reports/2005perceptions.htm. [Accessed 1 February 2010].

2. World Commission on Environment and Development, Our Common Future (New York: Oxford University Press, 1987), 43.

3. University Leaders for Sustainable Future, Talloires Declaration (Talloires: ULSF, 1990. Available online at www.ulsf.org/programs_talloires_td.html. [Accessed 1 February 2010].

4. CONCERN, Inc. and American Library Association Social Responsibilities Round Table. Task Force on the Environment, "Libraries Build Sustainable Communities," in Three Dynamics of Sustainable Communities: Economy, Ecology, and Equity. Available online at www.ala.org/ala/srrt/ tfoe/lbsc/librariesbuildsustainablecommunitiesthree.htm. [Accessed 1 February 2010].

5. C. Judson King, Harley, S. Earl-Novell, J. Arter, S. Lawrence, and I. Perciali, Scholarly Communication: Academic Values and Sustainable Models. (Center for Studies in Higher Education, Paper CSHE-16-06, 2005-2006), 2. Available online at http://cshe.berkeley.edu/research/scholarlycommunication/scholarlycomm_proposal.pdf. [Accessed 1 February 2010].

6. Laura Brown, Rebecca Griffiths, and Matthew Rascoff, University Publishing in a Digital Age. Ithaka Report (July 2007). Available online at www.ithaka.org/strategic-services/Ithaka\%20 University\%20Publishing\%20Report.pdf. [Accessed 1 February 2010].

7. Robert Schroeder and Gretta E. Siegel, "A Collaborative Publishing Model for Sustainable 
Scholarship," Journal of Scholarly Publishing 37, no. 2 (Jan. 2006): 86-98.

8. Kevin Guthrie and Wendy Lougee, "The JSTOR Solution: Accessing and Preserving the Past," Library Journal 122, no. 2 (Feb. 1997): 42-44.

9. Seamus Ross and Margaret Hedstrom, "Preservation Research and Sustainable Digital Libraries," International Journal of Digital Libraries 5 (Aug. 2005): 317-24.

10. Institute of Museum and Library Services, "Status of Technology and Digitization in the Nation's Museums and Libraries" (2006). Available online at www.imls.gov/resources/TechDig05/ Technology\%2BDigitization.pdf. [Accessed 1 February 2010].

11. Howard Besser, "The Next Stage: Moving from Isolated Digital Collections to Interoperable Digital Libraries," First Monday 7, no. 6 (June 2002). Available online at http://firstmonday. org/htbin/cgiwrap/bin/ojs/index.php/fm/article/view/958/0. [Accessed 1 February 2010].

12. Lawrence Lessig, The Future of Ideas: The Fate of the Commons in a Connected World (New York: Vintage, 2002); Don Schiller, How to Think About Information (Urbana, Ill.: University of Illinois Press, 2007).

13. Brian Lavoie, "The Fifth Blackbird: Some Thoughts on Economically Sustainable Digital Preservation," D-Lib Magazine 14, no. 3/4 (Mar./Apr. 2008). Available online at www.dlib.org/dlib/ march08/lavoie/03lavoie.html. [Accessed 1 February 2010].

14. Margaret Henty, "Ten Major Issues in Providing a Repository Service in Australian Universities," D-Lib Magazine 13, no. 5/6 (2007). Available online at www.dlib.org/dlib/may07/ henty/05henty.html. [Accessed 1 February 2010].

15. Deanna Marcum, "Preservation of Scholarship: The Digital Dilemma," The Internet and the University: Forum 2002 (Boulder, Colo.: Educause, 2002): 200. Available online at http://net. educause.edu/ir/library/pdf/ffpiu028.pdf. [Accessed 1 February 2010].

16. Jeanne M. Le Ber and Joan M. Gregory, "Becoming Green and Sustainable: A Spencer S. Eccles Health Science Library Case Study," Journal of Medical Library Association 92, no. 2 (2004): 266-68.

17. Maria A. Jankowska, "The Need for Environmental Information Quality," Issues in Science and Technology Librarianship 26 (Spring 2000). Available online at www.istl.org/00-spring/article5. html. [Accessed 1 February 2010].

18. Monika Antonelli, Fred Stoss, and Elaine Harger, "Cup by Cup: Librarians Raise Their Cups for Planet Earth" (press release, 2008). Available online at http://wikis.ala.org/midwinter2008/ index.php/Cup_by_Cup. [Accessed 1 February 2010].

19. Greening ACRL 2009. ACRL 14th National Conference in Seattle, 2009. Available online at www.ala.org/ala/mgrps/divs/acrl/events/seattle/green.cfm. [Accessed 1 February 2010].

20. James LeRue and Susan LeRue, "The Green Librarian," Wilson Library Bulletin 65 (Feb. 1991): 27-33.

21. C. Atton, "Green Librarianship: A Revolt against Change," Assistant Librarian 86 (Nov. 1993): $166-67$.

22. Katherine Dike, "How Green Is the Academic Sector?" Library plus Information Update 6, no. 7-8 (July/Aug. 2007): 57-59.

23. Kathleen Rickert, "Greening Our College Libraries: Complete the Cycle of the Three Rs," College E Research Libraries News 62, no. 8 (2001): 825-28.

24. Philip E. Ephraim, “The Greening of Libraries," Library Management 24, no. 3 (2003):160-64; Jennifer Pinkowski, “Keeping Track of Green Libraries," Library Journal 15 (Sept. 15, 2007), available online at www.libraryjournal.com/article/CA6475365.html [Accessed 1 February 2010]; Francine Fialkoff, "Green Libraries Are Local," Library Journal 11 (June 15, 2008), available online at www. libraryjournal.com/article/CA6566439.html [Accessed 1 February 2010].

25. Going Green @Your Library: Environmentally Friendly Practices for Libraries and Beyond!, available online at http://greeningyourlibrary.wordpress.com/ [Accessed 1 February 2010]; The Green Library, available online at http://thegreenlibraryblog.blogspot.com/ [Accessed 1 February 2010].

26. Jane Neale, "Go Green!" Library Journal 2 (Feb. 1, 2008), available online at www.libraryjournal.com/article/CA6523443.html [Accessed 1 February 2010]; Dorothy W. Trotter, "Going for the Green," American Libraries 39 (Apr. 2008): 40-43.

27. Monika Antonelli, "The Green Library Movement: An Overview and Beyond," Electronic Green Journal 1, no. 27 (2008). Available online at http://repositories.cdlib.org/uclalib/egj/vol1/ iss27/art1/. [Accessed 1 February 2010].

28. Georgia Briscoe, "Recycling: What's in It for Libraries?" American Libraries 87, no. 18 (Dec. 1987): 954-56; Georgia Briscoe, "Reuse, Reduce, Recycle," Library Journal 116, no. 17 (Oct. 15, 1991): 43-44.

29. Ann Eagan, "Noise in the Library: Effects and Control," Wilson Library Bulletin, 65 (Feb. 1991): 44-47.

30. Michele Calloway, "Paper Use and Recycling in Academic Libraries," Electronic Journal of 
Academic and Special Librarianship 4, no. 2-3 (Fall 2003); Tom Moothart and Linsey Wess, "Popularity Has Its Costs: Charging for Public Printing," Colorado Libraries 25, no. 1 (1991): 15-18; Beth Ashmore and Sara Morris, "From Scraps to Reams: A Survey of Printing Services in Academic Libraries," College \& Research Libraries 63, no. 4 (2002): 342-52.

31. Terry Link and The Task Force on the Environment, "Sources for a Small Planet: Environmental Bibliographies Reflect a Question of Values," Library Journal 115, no. 10 (1990): 81-88.

32. Maria A. Jankowska, "Librarian's Contribution to Scholarly Communication and Environmental Literacy," The Serials Librarian 49, no. 4 (2006): 117-24.

33. Frederick W. Stoss, "If We Are So Smart, Why Do We Need Environmental Education," Electronic Green Journal 1, no. 26 (2008). Available online at http://repositories.cdlib.org/uclalib/ egj/vol1/iss26/art1/. [Accessed 1 February 2010].

34. Irwin Weintraub, "Fighting Environmnental Racism: A Selected Annotated Bibliography," Electronic Green Journal 1, no. 1 (1994).

35. Flora Shored is publishing a regular column in Environmental Information Resources in Electronic Green Journal since 1996. The latest one is available at http://repositories.cdlib.org/uclalib/ egj/vol1/iss27/art4/. [Accessed 1 February 2010].

36. Linda Rome, “Celebrating Earth Day All Year Long,” Wilson Library Bulletin 65 (Feb. 1991): $40-43$.

37. Dike, "How Green Is the Academic Sector?" 57.

38. James Weiner and Lynn Boyden, "Creating Sustainable Libraries," Library Journal 126, no. 20 (supplement, Dec. 2001): 8-10.

39. Bill Brown, "The New Green Standard," Library Journal 128, no. 20 (Dec. 2003): 61-66.

40. Michael Dewe, Planning Public Library Buildings: Concepts and Issues for the Librarian (Burlington: Ashgate, 2006), 24-33.

41. Johanna Sands, Sustainable Library Design (Santa Monica: Libris Design, 2007). Available online at www.librisdesign.org/docs/SustainableLibDesign.pdf. [Accessed 1 February 2010].

42. S. Bennett, Libraries Designed for Learning, CLIR Report (2003). Available online at www. clir.org/PUBS/abstract/pub122abst.html [Accessed 1 February 2010]; J.V. Boettcher, "Ten Core Principales for Designing Effective Learning Environnements: Insights From Braine Research and Pedagogical Theory, "Innovate: Journal of Online Education 3, no 3 (Feb./Mar. 2007), available online at http://innovateonline.info/index.php?view=article\&id=54\&highlight=boettcher [Accessed 1 February 2010].

43. Sands, Sustainable Library Design.

44. United Nations, Indicators of Sustainable Development: Framework and Methodologies (1996). Available online at www.un.org/esa/sustdev/natlinfo/indicators/indisd/english/english.htm. [Accessed 1 February 2010].

45. Yale University, Environmental Sustainability Index (2005). Available online at www.yale. edu/esi/. [Accessed 1 February 2010].

46. David J. Eagan and David W. Orr, eds., "The Campus and Environmental Responsibility," New Directions for Higher Education 77 (Spring 1992); Sarah Hommond Creighton, Greening the Ivory Tower: Improving the Track Record of Universities, Colleges, and Other Institutions (Boston: MIT Press, 1998); Michael M'Gonigle and Justin Starke, Planet U: Sustaining the World, Reinventing the University (Gabriola Island: New Society Publisher, 2006); and Larry H. Litten and David Geronimo Terkla, eds., "Advancing Sustainability in Higher Education," New Direction for Institutional Research, 134 (Summer 2007).

47. The College Sustainability Report Card. Available online at www.greenreportcard.org [Accessed 1 February 2010].

48. Martie J Von Deventer and Retha Snyman, “Measuring for Sustainability: A Multi-dimensional Measurement Framework for Library and Information Services," Libri 54 (2004): 1-8.

49. Kevin R. Guthrie, Rebecca Griffiths, and Nancy Maron, Suitability and Revenue Model for Online Academic Resources: An Ithaka Report (May 2008). Available online at www.ithaka.org/ strategic-services/sca_ithaka_sustainability_report-final.pdf. [Accessed 1 February 2010].

50. "Advancement of Sustainability in Higher Education," AASHE Digest: An Annual Review of Campus Sustainability (2008). Available online at www.aashe.org/publications/digest.php. [Accessed 1 February 2010].

51. Primary Research Group (2008). Available online at www.primaryresearch.com. [Accessed 1 February 2010].

52. Maria A. Jankowska, "A Model for Environmentally Sustainable Library Operations and Services," Proposal to Librarians Association of the University of California (LAUC) University Wide Research Funds (Jan.2008): 4.

53. Ibid., 5 .

54. ALA Social Responsibilities Round Table, Three Dynamics.

55. Electronic Waste (e-waste) in Libraries and Archives (2007). Available online at http://srhkim. 
com/ewaste/index.html. [Accessed 1 February 2010].

56. Eco-Libris, How We Do It (2007). Available online at www.ecolibris.net/how.asp. [Accessed 1 February 2010].

57. WorldWatch Institute, Painless Paper Cuts (2008). Available online at www.worldwatch.org/node/1497. [Accessed 1 February 2010].

58. Michael Kanellos, "New Way to Save Energy: Disappearing Ink," CNET News (Apr. 29, 2008). Available online at http:// news.cnet.com/8301-11128_3-9930674-54. html?tag=mncol;txt. [Accessed 1 February 2010].

59. Donella H. Meadows, "Seven-plus Wonders of Sustainability," Grist (Aug. 30, 1999). Available online at www.grist.org/ comments/citizen/1999/08/30/of/index.html. [Accessed 1 February 2010].

60. Campus Sustainability Assessment (CSA) database. Available online at http:// csap.envs.wmich.edu/pages/res_csa.html. [Accessed 1 February 2010].

61. Ibid., 8.

62. Terry Link, "Transforming Higher Education through Sustainability and Environmental Education," Issues in Science and Technology Librarianship (Spring 2000). Available online at www.istl.org/00-spring/ article4.html. [Accessed 1 February 2010].

63. Maria A. Jankowska, "A Call for Sustainable Library Operations and Services," CERL News 69, no. 6 (June 2008): 323-24.

64. Kevin Kelly, New Rules for the New Economy (New York: Viking, 1999).

65. Xin Li, "Library as Incubating Space for Innovations: Practices, Trends and Skill Sets," Library Management 27, no. 6/7 (2006): 370-78.

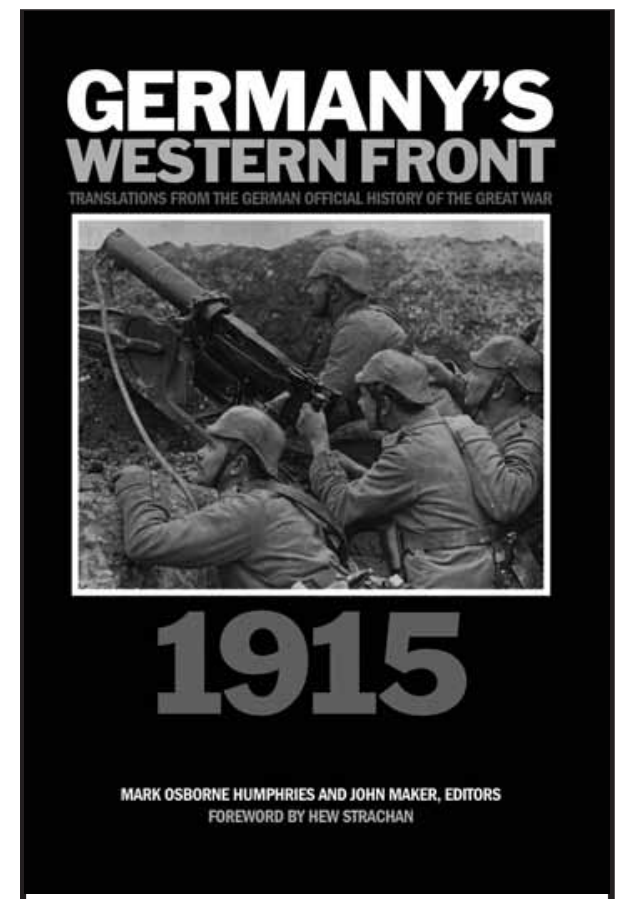

Germany's Western Front

Translations from the German Official History of the Great War, 1915

Mark Osborne Humphries and John Maker, editors

\$85.00 Cloth • 978-1-55458-051-4 • Co-published with the Laurier Centre for Military Strategic and Disarmament Studies

The first English translation of the German official history of the WWI, Der Weltkrieg, this volume focuses on 1915 and trench warfare, poison gas at Ypres, and conflict in the German High Command.

Music Traditions, Cultures, and Contexts

Robin Elliott and Gordon E. Smith, editors \$38.95 Paper • 978-1-55458-177-1

Raises important themes about understanding musical traditions as agents of social, cultural, and political change.

Canadian Women in Print,

$$
\begin{aligned}
& \text { 1750-1918 } \\
& \text { Carole Gerson }
\end{aligned}
$$

\$85.00 Cloth • 978-1-55458-220-4

First historical xamination of women's engagement with multiple aspects of print, from early diaries through temperance and suffragette advocacy.

Wilfrid Laurier University Press

Order through your wholesaler or call 1-800-565-9523 